\title{
The generational "exchange" rate: \\ How generations convert career development satisfaction into organisational commitment or neglect of work
}

Running head: The generational exchange rate

Keywords: Aging workforce; Employability; Commitment; discretionary effort

Name: $\quad$ John Benson

Institution: School of Business, Monash University Kuala Lumpur, Malaysia Department of Management Monash University Melbourne, Australia,

Email: $\quad$ john.benson@monsh.edu

Name: $\quad$ Michelle Brown

Institution: Department of Management and Marketing University of Melbourne, Carlton Victoria, Australia

Email: $\quad$ brownm@unimelb.edu.au

Name: $\quad$ Miriam Glennie

Institution: School of Business, University of New South Wales, Canberra, Australia.

Email: $\quad$ m.glennie@adfa.edu.au

Name: $\quad$ Michael O’Donnell

Institution: School of Business, University of New South Wales, Canberra, Australia.

Email: $\quad$ m.odonnell@adfa.edu.au

Name: $\quad$ Peter O'Keefe

Institution: School of Business University of New South Wales, Canberra, Australia.

Email: $\quad$ p.okeefe@adfa.edu.au

Funding information - none

Conflict of Interest Declarations - none

Acknowledgements - we thank the employees of PSR for their participation in our data collection process.

This is the author manuscript accepted for publication and has undergone full peer review but has not been through the copyediting, typesetting, pagination and proofreading process, which may lead to differences between this version and the Version of Record. Please cite this article as doi: $10.1111 / 1748-8583.12198$

This article is protected by copyright. All rights reserved. 


\title{
The generational "exchange" rate: \\ How generations convert career development satisfaction into organisational commitment or neglect of work
}

\begin{abstract}
Utilising social exchange theory, we investigate the exchange of career development satisfaction for organisational commitment and neglect of work. Employees can, however, show more or less reciprocity towards their organisation. We assess the role of generational membership (Baby Boomers versus Generation X) as a determinant of reciprocity. Boomers began work when jobs were "for life", they value job security and tend to rely on the organisation for their career direction. In contrast, Generation X generally commenced work during the recession of the early 1990's so they feel they cannot rely on one employer for a lifetime of employment. We investigate the extent to which generational differences in work and career values moderates the career development satisfaction- organisational commitment /neglect of work relationship. We find, using data from 1530 employees in one organisation, that Generation $\mathrm{X}$ are more likely to exchange high career development satisfaction for higher levels of organisational commitment and lower neglect of work than Boomers.
\end{abstract}

Keywords: Aging workforce, Employability, Commitment, Discretionary effort 
Social exchange theory (Blau, 1964; Gouldner, 1960) suggests that when an employee receives something of value from an organisation they will reciprocate; when the organisation is unfair to an employee they will punish it. The exchange of resources is therefore key to social exchange theory (Cropanzano \& Mitchell, 2005). The purpose of this paper is to investigate the exchange of career development satisfaction for organisational commitment (positive reciprocity) and neglect of work (negative reciprocity), and the effect of generational membership on the extent to which career development satisfaction is converted into organisational commitment or neglect of work.

Career development satisfaction is a facet of subjective career success (Greenhaus, Parasuraman \& Wormley, 1990). Subjective career success refers to individuals' evaluation of their career progress, accomplishments and anticipated outcomes, relative to their own goals and aspirations (Seibert \& Kraimer, 2001). Focussing on an internal criterion for career success (career development satisfaction) aligns with the current careers context where employees are expected to self-manage their own careers rather than rely on organisational direction (Hall \& Mirvis, 1996). It is important to understand the consequences of career development satisfaction as it can impact on the capacity of the organisation to manage employees effectively. We assess the impact on organisational commitment and neglect of work; the former representing an attitudinal response whilst the latter a behavioural response.

We focus on the two largest Australian generational cohorts: 'Baby Boomers' (born 1946 to 1961) and 'Generation X' (born 1962 to 1975). In the period July 2000 to July 2016 the Australian workforce grew from 9 to 12 million (Salt, 2016). Twenty percent of the growth came from Generation X and 40\% from Baby Boomers. Boomers now occupy one in 
three jobs in the Australian economy and are keen to remain in the workforce (NSR, 2017). Boomers are in better health than earlier generations (who undertook hard physical work so had to retire at an earlier age), especially those who work in white collar occupations and/or knowledge industries. Boomer participation in the labour market is also being promoted by government policy, by pushing back the age at which employees can access funds for retirement.

Generation $\mathrm{X}$ are generally mid-career employees and who are waiting to step up to fill the positions currently occupied by Boomers. By working to an older age than previous generations, Boomers are impacting on the career options for Generation X. There is some evidence of conflict between these two generations (Jurkiewicz, 2000). From an organisation's perspective, the challenge is to ensure that there is an alignment of the interests of all its employees with those of the organisation.

The study contributes to the literature in three ways. First, much of the generational research to date has applied USA generational definitions, even for those studies conducted outside of the USA. Yet, generational theory contends that generations develop within a specific socio-historical location meaning that is it inappropriate to apply the USA generational definition to other countries (Lyons \& Kuron, 2014). We define our generations (Baby Boomer and Generation X) based on historical and social experiences in Australia. Second, while the norm of reciprocity is widely accepted, research is needed to understand when and why employees show more or less reciprocity toward their organisations (Chen, Chen \& Portnay, 2009). The paper identifies generational membership as a determinant of the level of reciprocity. Third, we examine both positive (organisational commitment) and 
negative (neglect of work) reciprocity in response to satisfaction with career development opportunities. To understand the social exchange relationships, both positive and negative aspects need to be analysed concurrently (Gibney, Zagenczyk \& Masters, 2009).

\section{Social exchange theory}

Social exchange involves the trading of any resource that can be transferred between people (Foa \& Foa, 1974) and creates an informal, open ended obligation. Social exchanges can occur between individuals as well as between employees and their employing organisation (Eisenberger et al., 2001). A social exchange relationship within an organisation evolves when employers take care of employees, which thereby engenders beneficial consequences (Cropanzano \& Mitchell, 2005).

The norm of reciprocity suggests that individual employees will respond to their organisation in kind. Norms of reciprocity can be positive (individuals responding to positive treatment with positive conduct) and negative (individuals responding to negative treatment with negative conduct) (Gouldner, 1960). While there are several important exchange relationships that occur between employers and employees, such as those involving pay and working conditions, one area often neglected by management is career development (Kaye \& Giuliono, 2012).

\section{Career development and organisational commitment}

Traditional careers are a hierarchical progression through an organisation (Lyons, Schweitzer \& Ng, 2015). Such careers are predictable (Hess, Jepsen \& Dries, 2012), centrally planned and formally documented. Steady upward moves within the organisation occurs in exchange for employee loyalty (Chudzikowski, 2012). Some, but not all, researchers suggest the 
traditional career has been replaced by the protean career (Van der Heijden, et al., 2009) or the boundaryless career (Sullivan \& Arthur, 2006), both of which require individuals to be responsible for their own employability. In the "new" career, employees remain with the organisation in exchange for learning and development opportunities that assist with the overall employability (Baruch, 2006). Hence, irrespective of the type of career (traditional or new), an employee's career development satisfaction can be reciprocated in the form of organisational commitment.

Career development is a form of support (Mullen et al., 2006) that is often perceived by employees as demonstrating organisational care and recognition of their efforts (Bashir \& Long, 2015). Employees reciprocate positively through a stronger attachment to the organisation when they perceive supportive treatment from their employers (Blau, 1964; Eisenberger et al., 2001; Ng et al., 2005).

Satisfaction with career development is positively associated with organisational commitment (Bambacas, 2010; Tansky \& Cohen, 2001). Satisfaction with types of career development activities such as training courses (Bashir \& Long, 2015; Galanou \& Priporas, 2009) and workshops (De Vos, Dewettinck and Buyens, 2009) also have a positive effect on organisational commitment. We therefore hypothesise that:

H1: There will be a positive relationship between career development satisfaction and organisational commitment.

\section{Career development and neglect of work}

Consistent with social exchange theory, in the absence of career development satisfaction employees may feel their contributions to the organisation are not appreciated and may 
reciprocate in a manner that will harm the organisation (Gibney et al., 2009) such as neglecting their work. Neglect is an employee's 'temporary abandonment and psychological inattention' (Farrell, 1983, p. 598) of, and to, work. Neglect is characterized by reduced effort and interest in work (Vigoda, 2002) and includes behaviours such as chronic lateness, reduced interest and effort, absenteeism and pursuing personal business or activities during work time (Allen \& Tuselmann, 2009; Hagedoorn et al., 1999; Rusbult et al., 1988). Neglect of work is harmful to the organisation as employees are scaling down their work contributions (Naus, van Iterson \& Roe, 2007).

There is limited research on career development satisfaction and its relationship to neglect of work, though research on career development satisfaction and other withdrawal behaviours such as turnover, lateness and absenteeism is instructive. Each of these behaviours, like neglect, can involve the scaling down of work effort and less interest in the organisation. Turnover decisions can be based on a negative evaluation of career opportunities (Ng et. al., 2005), while dissatisfaction with career is associated with lateness and absenteeism (Blau, Tatum \& Cook, 2004; Carmeli et al., 2007).

The employee with low career development satisfaction may form the view that they have reached their career limit in the organisation (Day \& Allen, 2004). In the absence of career prospects, the employee may reciprocate by neglecting their work. The failure to meet employee development expectations will reduce the employee's trust and confidence in management and the organisation which, in turn, will undermine the employee - employer relationship (Naus et al., 2007). Employees who feel unwanted by the organisation will 
reciprocate with higher levels of neglect of work (Eisenberger et al. 2001). We hypothesise that:

H2: There will be a negative relationship between career development satisfaction and neglect of work.

\section{Generations, organisational commitment and neglect of work}

Employees can show more or less reciprocity toward their exchange counterpart, the organisation (Chen et al., 2009) and there is evidence of cultural and individual differences affecting the level of reciprocity (Shore \& Coyle-Shapiro, 2003). We build on these findings to test the role of generational membership as a determinant of the level of reciprocity.

Generational cohort theory stems from the work of Mannheim (1952 [1923]) which defines a generation as a 'group of people or cohorts who share birth years and experiences as they move through time together, influencing and being influenced by a variety of critical factors' (Kupperschimdt, 2000, p. 66). "Critical” factors include changing societal attitudes, key political, economic and social events, and significant incidents that have meaning at that time to that generation. Major social, political and economic changes create uncertainty for people, causing people to try to make sense of what is going on (Weick, 1995). Sense making involves the search for meaning to deal with uncertainty. Change encourages people to talk with one another to develop a plausible interpretation of the changes (Drazin, Glynn \& Kazanjian, 1999) and to limit the potentially detriment effects on their well-being (Elrod II \& Tippett, 2002). The "double interact" process (Morgeson \& Hofmann, 1999) occurs which people share some thoughts with another person, who responds back. The reciprocal 
interaction creates collective values (Nishi, Lepak \& Schneider, 2008) and what they will do to satisfy these values (Twenge et al., 2010).

Baby Boomers (1946 to 1961)

After the Second World War, men returned to civilian employment and the Australia government encouraged women to return to the home to have children. The following years were characterised by high marriage and increasing fertility rates. The number of births increased steadily throughout the 1950s and peaked in 1961 when 240,000 babies were born, hence the term "baby boomers". The birth rate fell from 1961 as social and economic changes led to a wider use of oral contraceptives (ABS, 2002). Boomers were protected by parents who experienced the Great Depression and were raised in the prosperous post-war era.

Boomers entered adulthood in the early 1970's, a period of significant social, economic and political change. Boomers opposed the Vietnam War and supported changes in attitudes to women's status and roles within the family, education, labour market, politics and society. Boomers views found a political voice in a new Labor leader, with policies designed to get their votes through free university education, withdrawing Australian troops from Vietnam and anti-discrimination laws for indigenous people.

The experiences of their formative years had an impact on the work values of Boomers. They believe in fairness and equal opportunity which led to a preference for hierarchal structure in organisations (Miller \& Yu, 2003) and a respect for authority (Gursoy, Maier \& Chi, 2008). Boomers began work when jobs were "for life" and are motivated by a need for job security (Australian Institute of Company Directors, 2012). Work is central to the lives of Boomers (Smola \& Sutton, 2002) and believe that the key to employability is 
working hard and being loyal to their organisation (Sirias, Karp \& Brotherton, 2007). They are more likely to rely on their organisation for career development direction than Generation X (Lyons, Schweitzer \& Ng, 2015) because they value fit with the organization (Hess \& Jepson, 2009).

\section{Generation X (1962 to 1975)}

Generation X were the first Australian generation to grow up with divorce and working mothers. They are often referred to as 'latch-key' kids. They were brought up in an era of considerable technological change and are, on average, more highly educated than Boomers. Generation X watched their parents work hard for their organisations only to be retrenched or have harsher working conditions imposed during the 1990s-financial crisis (AICD, 2012). Many Generation X entered the workforce in the recession of the 1990's which heralded the decline of well-paid manufacturing jobs and the rise of lower paid service work.

These experiences taught Generation $\mathrm{X}$ that loyalty was no longer valued by organisations, nor that they would be able to rely on one employer for a lifetime of employment. Generation X are therefore more individualistic than Boomers (Twenge, Campbell \& Freeman 2012) and feel less obligated to their organisation (Hess \& Jepson, 2009). Generation X often assume self-direction of careers (Lyons, Schweitzer \& Ng, 2015) but expect development opportunities within the organisation (Hamori, Cao \& Koyunci 2012). Generation $X$ typically take the view that the "employing organisation now serves as the vehicle for career development, rather than the driver' (Lyons et al., 2012, p. 346). They generally expect to attain and maintain career security and enhance their marketability 
through challenging jobs in which they are constantly learning and through employer provided on-the-job training and opportunities to continue their formal education (Sayer, 2007). Some commentators argue that "Generation Xers are "addicted to learning", (Lyons, Duxbury \& Higgins, 2005, p. 69).

Employees who have a high need to develop their skills are more likely to take steps to ensure their needs are met (Hess et al., 2012). Gentry and colleagues (2011) found that career issues were more important to Generation X than to Boomers. Further, Generation X are used to instant gratification due to use of gaming technology in their formative years so are more likely to react when their needs are not meet (Westerman \& Yamamura, 2007): they are less patient and less willing to wait for promotion than Boomers (Gursoy, Maier \& Chi 2008), are more likely to be dissatisfied with their career progression (Hewlett, Sherbin, \& Sumberg 2009), and often expect immediate recognition through praise and promotion than Boomers. Generation $\mathrm{X}$ are quick to capitalise on job opportunities elsewhere if they do not get their way (Lyons et al., 2012).

The positive relationship between career development satisfaction and organisational commitment will therefore be stronger among Generation X employees. When Generation X perceive career development satisfaction they reciprocate with higher levels of organisational commitment. In contrast, the positive relationship between career development satisfaction and organisational commitment will be weaker among Boomer employees. Moreover, Boomers have reciprocation wariness: their extended workforce experiences make them less inclined to respond to their organisation (Cotterell, Eisenberger \& Speicher, 1992). We hypothesise that: 


\section{H3: Generation moderates the positive relationship between career development} satisfaction and organisational commitment. The relationship is stronger for

\section{Generation X than for Boomers.}

Similarly, Generation X are more likely to act when they experience career development dissatisfaction - they generally believe that little is permanent and so they over emphasise the importance of their current needs (Westerman \& Yamamura, 2007). Further, they believe they have more to offer - quick to learn, stronger information technology skills as they have been using it for most of their lives and are more comfortable with change. Combined with the impact of negative stereotypes about older workers on the demand for Boomer employees, Generation X feel they have a labour market advantage. Generation $\mathrm{X}$ therefore perceives few risks in reciprocating their dissatisfaction with their career development by neglecting their work.

In contrast, the negative relationship between career development satisfaction and neglect of work will be weaker among Baby Boomers. Boomers generally believe in hard work as the way to advance their careers, so neglecting their work is contrary to their work values. Further, neglecting work is a potentially high-risk response for Boomers as its manifestations (for example, chronic lateness) are obvious to others. Boomers have higher sunk costs in their organisation (pensions, accumulated leave entitlements) and may find it harder to obtain an alternative position due to age discrimination in the labour market (AHRC, 2015). We therefore hypothesise that: 
H4: Generation moderates the negative relationship between career development satisfaction and neglect. The relationship is stronger for Generation X than for Boomers.

\section{Methodology}

\section{Setting and subjects}

The case study organisation is an Australian, public-sector research organisation (PSR) whose primary roles are to carry out scientific research, assist industry, and to encourage and facilitate the application and use of scientific research. PSR facilitates research across a wide variety of fields including agriculture, astronomy, engineering, health, renewables and information technology. For researchers, and those who seek to support scientific research, this is a prestigious place to work. PSR has a strong internal development focus, with a focus on individual development aligned to the achievement of PSR's strategic mission. The obligation to provide career development support is also detailed in the enterprise agreement covering employees at PSR. The unique nature of the required staff development has required PSR to invest heavily in a wide range of specific development activities and programs. Therefore, employees tend to stay with PSR: the average tenure for a Boomer is 19 years and for a Generation $\mathrm{X}$ it is 11 years.

At the time of the research PSR employed about 6,000 employees, under a standard set of employment conditions and collective agreements, and which included scientists, tradespersons, technicians, clerical and managerial employees. Nearly half the workforce 
were members of the PSR Staff Association, and union coverage extended to all employees up to mid-level managerial staff.

\section{Data}

In collaboration with the PSR Staff Association all workplace representatives were asked to offer a copy of the survey to each employee in their work unit irrespective of the employee's union status. In total, 4,280 questionnaires were distributed to union and non-union employees. Questionnaires were returned directly to the researchers by a postal, reply-paid envelop or the sealed envelopes were collected by union representatives and then forwarded in bulk to the researchers. The number of returned questionnaires was 2,116 which represented an overall response rate of 49.4 per cent.

Respondents were generally representative of the PSR workforce within the various divisions $(\mathrm{t}=.06, \mathrm{df}=7921, \mathrm{p}=.56)$, although there was an over-representation of union members $(t=11.12, \mathrm{df}=8613 \mathrm{p}<.0001)$. As the study was concerned with Boomers and Generation $\mathrm{X}$ others respondents outside this range were excluded from the analysis, generating an effective sample of 1,530 employees with fifty six percent of the sample classified as Boomers and 44 per cent as Generation X. Following Shaw et al. (1998) we compared our generational sample against the full sample using the same criteria. In the logistic regression division was not statistically significant, although union membership was.

\section{Measures}

Dependent variables. Organisational commitment was measured by the nine-item scale by Porter et al. (1974). A representative item is 'I promote PSR to my friends as a great place to work'. The nine items were averaged to form a single scale score $(\alpha=.88)$. Neglect of work 
was measure by a five-item scale by Hagedoorn et al. (1999). A representative item is 'I miss out on meetings because I do not feel like attending them'. The items were averaged to form a single scale score $(\alpha=.79)$.

Predictor variable: Career development satisfaction was measured by three items from the Career Satisfaction scale. Greenhaus, Parasuraman and Wormley (1990) point out that subjective career success has many facets including satisfaction with career development. We asked about "Your Career at PSR" using the following items 'I am satisfied with the progress I have made toward meeting my overall career goals', 'I am satisfied with the progress I have made toward meeting my goals for advancement', and 'I am satisfied with the progress I have made toward meeting my goals for the development of new skills' $(\alpha=.83)$. Generation was based on birth year with employees born from 1946 to 1961 classified as Baby Boomers (=1) and those born from 1962 and 1975 classified as Generation X (=0). Moderator variable: This centred variable was created by multiplying career development satisfaction by Generation.

Control variables: We included a range of control variables to account for career effects. We controlled for task interdependency (three items from Kiggundi, 1983; $\alpha=.83$ ) as the level of job interdependence decreases as an employee progresses through their career (Fried \& Ferris, 1987). A representative item is 'my job depends on the work of many different people for its completion'. We included the availability of performance feedback (five items from Steelman, Levy \& Snell, 2004; $\alpha=.81$ ) as supervisors are more likely to provide feedback at the early stages of an employee's career (Fried, Tiegs \& Bellamy, 1992). A representative item is 'my supervisor is usually available when I want performance 
information'. We included alternative job opportunities as a measure of the current labour market (single item, 5-point scale: $1=$ no chance, $5=100 \%$ chance; from Griffeth $\&$ Hom, 1988). As Brown, et. al. (2003) note, an employee's perception of career development satisfaction can be affected by the state of the labour market. Adequate resources (6 items based on Iverson (1992)) are important for the achievement of career goals. A representative item is 'the facilities I need for my work are readily available to me' $(\alpha=.82)$.

Individuals progress through career stages during their work live, which can impact attitudes and behaviours. Super's (1957) Career Development Model identifies three career stages - establishment, advancement and maintenance. Total tenure with an organisation is often used as an objective measure of career stage (Demerouti, Peeters \& van der Heijden, 2012; Kooij \& Boon, 2018; Lam, Ng \& Feldman, 2012). Consistent with Conway (2004) and Kooij, \& Boon (2018) we define the establishment career stage as organisational tenure $\leq 2$ years, the advancement stage (organisational tenure 2-10 years), and the maintenance stage (organisational tenure $>10$ years. Maintenance stage is the omitted category.

We also control for employee demographic characteristics: education (whether the employee had a $\mathrm{PhD}$; yes $=1$, no =0), dependents (whether the employee had any dependents; yes $=1$, no $=0$ ), and negative affect (three items from Watson, Pennebaker and Folger, 1987; $\alpha=.87$ ). A representative item is 'minor setbacks sometimes irritate me too much', and union membership (whether respondent was a member of the union yes $=1$, no $=$ 0). We also include co-worker support (three items from House, $1981 ; \alpha=.91$ ) as supportive co-workers are associated with higher organisational commitment (Mathieu \& Zajac, 1990). A representative item is 'my peers are helpful to me in getting my job done'. 
Descriptive statistics for all study variables (by Generation) and the variable correlations are presented in Table 1.

[Insert Table 1 about here]

\section{Discriminant validity, common method variance and measurement invariance}

Before creating the composite variables for our study, we tested for configural and metric invariance (Cheung \& Rensvold, 2002). It is necessary to check for measurement invariance to determine if survey items mean the same thing to Boomers and Generation $\mathrm{X}$ (Cheung \& Rensvold, 2002). We ran a configural model using the technique outlined by Gaskin (2013). Configural invariance tests whether the CFA factor structure achieves adequate fit when Boomers and Generation $\mathrm{X}$ are tested together and freely (i.e. without any cross-group path constraints). When the model fits well there is configural invariance. Our configural model fit indices were good $\left(\chi^{2}(228, \mathrm{n}=1530)=846.03, p<.01 ; \mathrm{CFI}=0.95\right.$; TLI $=0.93 ; \mathrm{RMSEA}=0.04 ; \mathrm{SMRM}=.05)$. We also tested for metric invariance where all the factor loadings for Boomers and Generation X are constrained to be equal. Our metric model fit indices were $\operatorname{good}\left(\chi^{2}(242, \mathrm{n}=1530)=863.58, p<.01 ; \mathrm{CFI}=0.94 ; \mathrm{TLI}=0.93 ; \mathrm{RMSEA}=\right.$ 0.04; SMRM $=0.05)$. A chi square difference test between the configural and metric model $\left(\chi^{2}=17.55, \mathrm{df}=14, \mathrm{~ns}\right)$ indicated that there is measurement invariance.

Having established that our survey items are the same underlying latent construct for both generations we then assessed the discriminant validity of the scales and checked the potential for common method variance. A three-factor model (with latent variables representing career development satisfaction, organisational commitment and neglect) generated a significant chi-square $\left(\chi^{2}(116, \mathrm{n}=1530)=738.43, p<0.01 ; \chi^{2} / \mathrm{df}=6.48\right)$. In 
larger samples (greater than 400), the chi-square is likely to be significant (Kline, 1998), although there is no agreement on the cut-off value of the chi-square/d.f. test as a measure of model fit (Kline, 1998). In these cases, Dilalla (2000) recommends using a variety of fit indices. The fit indices showed a good degree of fit $(\mathrm{CFI}=0.95 ; \mathrm{TLI}=0.94 ; \mathrm{RMSEA}=0.06$; SMRM $=0.05)$. An examination of the individual factor loadings revealed that all loadings were significant and exceeded the minimum recommended value of .40 (Holtman, Tidd \& Lee, 2002).

A comparison of the three-factor model with a one factor model demonstrated that the latter was a much poorer fitting model $\left(\chi^{2}(119, \mathrm{n}=1530)=3610.77, p<.01 ; \chi^{2} / \mathrm{df}=30.86\right)$, as confirmed by the fit indices $(\mathrm{CFI}=0.69 ; \mathrm{TLI}=0.64 ; \mathrm{RMSEA}=0.138 ; \mathrm{SRMR}=0.173)$. If common method variance is largely responsible for the relationship among the variables, the one-factor CFA model should fit the data well (Korsgaard \& Roberson, 1995). This was not the case. The chi-square difference test of the one and three factor models was significant $\left(\chi^{2}\right.$ $=2872.34, \mathrm{df}=3, \mathrm{p}<.01)$, so the analyses are based on the three-factor model.

The study design minimizes the potential for common method variance (CMV): a large sample size $(n=1,530)$ and many predictor/control variables $(n=13)$. Under these circumstances, CMV is unlikely to be a problem (Siemsen, Roth \& Oliveira, 2010). Further, we are interested in the moderating role of Generation on the relationship between career development satisfaction and two outcome variables. Siemsen et al. (2010) demonstrate that CMV reduces the chances of finding a significant interaction effect. Finding a significant interaction effect, per Siemsen et al (2010), is evidence that CMV is not affecting the results. The moderator variable is Generation which is based on an objective phenomenon - 
employee age. The use of objective measures (rather than attitudes) mitigates common method variance (Conway \& Lance, 2010).

\section{Results}

Our hypotheses were tested using OLS regression techniques. Hypothesis 1 predicted that there would be a positive relationship between career development satisfaction and organisational commitment. In model 1 (Table 2), there was a positive and significant relationship between career development satisfaction and organisational commitment $(\mathrm{B}=$ $0.181, \mathrm{p}<.01)$. Hypothesis 1 is therefore supported.

[Insert Table 2 about here]

Hypothesis 2 predicted there would be a negative relationship between career development satisfaction and neglect of work. In model 3 (Table 2), there was a negative and significant relationship between career development satisfaction and neglect of work, irrespective of the measure of career stage $(B=-0.122, \mathrm{p}<.01)$. Hypothesis 2 is thus supported.

Hypothesis 3 predicted that Generation would moderate the positive relationship between career development satisfaction and organisational commitment. The interaction term (Career development satisfaction x Generation) is significant, irrespective of the measure of career stage (Model 2, B= -.073, p<.05). The inclusion of the interaction term had a significant effect on the explanatory of the model $\left.\left(\mathrm{F}_{1,1516}\right)=5.518, \mathrm{p}<.05\right)$. The effect size of the interaction is .003 (Aguinis, 2004), which is larger than the median effect size of .002 observed by Aguinis et al. (2005) in a 30-year review of moderator studies. The interaction results in model 2 were plotted using the procedures recommended by Aiken and 
West (1991). Figure 1 plots the relationship between career development satisfaction and organisational commitment for Boomers and Generation X. The analysis of the slope coefficients indicated that the career development - organisational commitment relationship was positive and significant for Generation $\mathrm{X}$ (slope coefficient $=0.214, \mathrm{p}<.01$ ) and positive and non-significant for Boomers (slope coefficient $=0.141$, ns). Hypothesis 3 is therefore supported.

Hypothesis 4 predicted that Generation would moderate the negative relationship between career development satisfaction and neglect. The interaction term (Career development satisfaction $x$ Generation): Table 2, model 4was $B=.082, p<05$ ). The inclusion of the interaction term had a significant effect on the explanatory of the model $\left(\mathrm{F}_{1,1516}\right)=$ 5.336, $\mathrm{p}<.05$ ). The effect size of the interaction is .003 (Aguinis, 2004), which is again larger than the median observed effect size of .002 (Aguinis et al., 2005). The interaction result in model 4 were plotted (Figure 2) using the procedures recommended by Aiken and West (1991). The analysis of the slope coefficients indicated that the career development - neglect of work relationship was negative for both generations but only significant for Generation X $($ Boomers slope coefficient $=-0.080, \mathrm{~ns}$; Generation $\mathrm{X}$ slope coefficient $=-0.159, \mathrm{p}<.01)$. Further, at any level of career development satisfaction, Generation X were more likely to neglect their work relative to Boomers (see Figure 2). Hypothesis 4 is thus supported.

[Insert Figures 1 and 2 about here]

\section{Discussion and conclusions}

We investigated the career development satisfaction - organisational commitment/neglect of work relationship. We found employees who reported high levels of 
career development satisfaction reciprocated with higher levels of organisational commitment and lower levels of neglect of work. However, the extent of reciprocation depended on the generational membership of the employee. Generation X employees reciprocate career development satisfaction both positively (with organisational commitment) and negatively (with neglect of work). Boomers did not reciprocate with either organisational commitment or neglect of work.

This study provides three contributions to research. First, we confirm the value of generational cohort theory. Following Mannheim (1952, p. 380), who argued that 'the unity of generations is constituted essentially by a similarity of location of a number of individuals within a social whole', we linked the definitions of Baby Boomers and Generation X to significant social, economic and political events in Australia. Second, much of the current generational research focuses on whether there are differences in generational work values. We extend generational cohort theory by evaluating whether generational differences matter. Our research suggest that an employee's perception of their career development satisfaction is determined, in part, by their generational membership. We find that Generation $\mathrm{X}$ employees, who have a high need to develop their skills and experience, are more likely to take steps to ensure their needs are met (Hess et al., 2012). Third, our findings extend social exchange theory by identifying a determinant of the level of reciprocity. Researchers have identified cultural and individual differences that affect the level of reciprocity (Shore \& Coyle-Shapiro, 2003). We find that generational membership exaggerates or attenuates the level of positive or negative reciprocity.

\section{Policy and practice implications}

This article is protected by copyright. All rights reserved. 
For human resource (HR) professionals, employee career management is a risk management process (Baruch, 2006): maximising the organisational returns from limited budgets. The process is made more complex when employees make, and act upon, subjective evaluations of their career development satisfaction. Our finding highlight the importance of including employee's preferences in a training needs analysis. A needs analysis typically identifies a gap between the needs of the organisation and the skills of its employees, but generally does not include an evaluation of an employees' work and career values.

Organisations are encouraged to consult with their employees to ensure that the type and frequency of career development initiatives align with the expectations of their employees. HR professionals should also be ensuring managers provide developmental feedback when conducting performance appraisals. These one-on-one meetings provide an opportunity for each employee to get tailored feedback on the opportunities that exist in the organisation. Employees will perceive developmental feedback as demonstrating that the organisation cares.

Our results may tempt organisations to focus their efforts on Generation X employees. Boomers through their work ethic and years of workplace experience are the repository of organisational knowledge so should not be overlooked. By establishing strong knowledge management and transfer programs, such as documentation, job transfers and mentor relationships, HR leadership can ensure that Boomers' critical experience and knowledge is shared with Generation X (Murphy, 2012). This will provide Generation X with the skills and experiences they seek and potentially breakdown negative generational stereotypes and intergenerational conflict. 


\section{Strengths, limitations and directions for future research}

All respondents were employed in the same organisation and were subject to the same HR policies. Our research design thus reduced a potential source of bias as differences in respondents' assessment of their career development satisfaction could not be attributed to differences in HR policies. Moreover, as PSR is confined to Australia all employees are subject to federal employment laws irrespective of their location. Further, despite employee reluctance to report deviant behaviour due to fears of employer retaliation (Cortina \& Magley, 2003), we could test a predictor (career development satisfaction) of neglect of work.

All studies have limitations and this one is no exception. The use of self-report measures leaves the research vulnerable to the potential biasing effect of common methods, though the tests for CMV demonstrated this is not a problem. There is an assumption of generational homogeneity though it is possible that not all Boomers or Generation $\mathrm{X}$ will have experienced the same events during their adolescence due to different geographical locations, cultures and actual birth years. Nevertheless, by creating specific Australian generational classifications such effects will be minimized.

Future researchers should test our findings using employees who work in blue-collar jobs. Our study was based in a knowledge-based organisation with white-collar workers who are typically in better health due to the less physically onerous working conditions. The less

physically demanding conditions can mean that they expect to be able to work longer than those whose work involves physical labour. Expectations of a longer career may influence white-collar career development satisfaction. Researchers might also investigate the impact 
of generations on the conversion of other supportive HR practices, such as work-life balance or employee voice on employee attitudes and behaviours.

This article is protected by copyright. All rights reserved. 


\section{References}

Aguinis, H. (2004). Regression Analysis for Categorical Moderators. New York: The Guilford Press.

Aguinis, H., Beaty, J. C., Boik, R. J., \& Pierce, C. A. (2005). Effect size and power in assessing moderating effects of categorical variables using multiple regression: A 30year review. Journal of Applied Psychology, 90 (1), 94-107.

Aiken, L., \& West, S. (1991). Multiple regression: Testing and interpreting interactions. Newbury Park: Sage.

Allen, M., \& Tuselmann, H. (2009). All powerful voice? The need to include "exit", "loyalty" and "neglect" in empirical studies too. Employee Relations, 31 (5), 538-552.

ABS (2002). Australian Social Trends, Australian Bureau of Statistics, catalogue number 4102.0.

AHRC (2015). National prevalence survey of age discrimination in the workplace. Canberra: Australian Human Rights Commission.

AICD (2012). The changing face of Australia. ASX 200 Roundtable Summary paper 2012, Australian Institute of Company Directors. Retrieved July 10, 2017 from: http://www.companydirectors.com.au/ /media/resources/director-resourcecentre/directorship-in-your-organistation/asx200/summary-paper_the-changing-face-of$\underline{\text { australia.ashx }}$

Bambacas, M. (2010). Organizational handling of careers influences managers' organizational commitment. Journal of Management Development, 29 (9), 807-827. 
Baruch, Y. (2006). Career development in organizations and beyond: Balancing traditional and contemporary viewpoints. Human Resource Management Review, 16 (2), 125138.

Bashir, N., \& Long, C. (2015). The relationship between training and organizational commitment among academicians in Malaysia. Journal of Management Development, $34(10), 1227-1245$.

Blau, G. (1964). Exchange and social life. New York: Wiley.

Blau, G., Tatum, D. S., \& Cook, K. W. (2004). Comparing correlates for different types of absence versus lateness behaviors. Journal of Allied Health, 33(4), 238-246.

Brown, S., McNabb, R., \& Taylor, K. (2006). Firm performance, worker commitment and loyalty, Sheffield Economic Research Paper Series, 2006005, University of Sheffield.

Carmeli, A., Shalom, R., \& Weisberg, J. (2007). Considerations in organizational career advancement: what really matters? Personnel Review, 36(1/2), 190-205.

Chen, Y., Chen, X., \& Portnoy, R. (2009). To whom do positive norm and negative norm of reciprocity apply? Effects of inequitable offer, relationship, and relational-self orientation. Journal of Experimental Social Psychology, 45 (1), 24-34.

Cheung, G. W., \& Rensvold, R. B. (2002). Evaluating Goodness-of-Fit Indexes for Testing Measurement Invariance. Structural Equation Modeling: A Multidisciplinary Journal, $9(2), 233-255$.

Chudzikowski, K. (2012). Career transitions and career success in the 'new' career era. Journal of Vocational Behavior, 81, 298-306. 
Conway, J., \& Lance, C. (2010). What reviewers should expect from authors regarding common method bias in organizational research. Journal of Business and Psychology, $25(3), 325-334$.

Cotterell, N., Eisenberger, R., \& Speicher, H. (1992). Inhibiting effects of reciprocation wariness on interpersonal relationships. Journal of Personality and Social Psychology, 62(4), 658-668.

Conway, E. (2004). Relating career stage to attitudes towards HR practices and commitment: Evidence of interaction effects? European Journal of Work and Organizational Psychology, 13(4), 417-446.

Cortina, L., \& Magley, V. (2003). Raising voice, risking retaliation: Events following interpersonal mistreatment in the workplace. Journal of Occupational Health Psychology, 8 (4), 247-265.

Cropanzano, R., \& Mitchell, M. (2005). Social Exchange Theory: An Interdisciplinary Review. Journal of Management, 31 (6), 874-900.

Day, R., \& Allen, T. (2004). The relationship between career motivation and self-efficacy with protégé career success. Journal of Vocational Behavior, 64 (1), 72-91.

Demerouti, E., Peeters, M. C. W., \& van der Heijden, B. (2012). Work-family interface from a life and career stage perspective: The role of demands and resources. International Journal of Psychology, 47(4), 241-258.

De Vos, A., Dewettinck, K., \& Buyens, D. (2009). The professional career on the right track: A study on the interaction between career self-management and organizational career 
management in explaining employee outcomes. European Journal of Work and Organizational Psychology, 18(1), 55-80.

Dilalla, L. F. (2000). Structural equation modeling: Uses and issues. In H. Tinsley and S. Brown (Eds.), Handbook of applied multivariate statistics and mathematical modeling (pp. 440-456). San Diego: Academic Press.

Drazin, R., Glynn, M. A., \& Kazanjian, R. K. (1999). Multilevel theorizing about creativity in organizations: A sensemaking perspective. Academy of Management Review, 24(2), 286-307.

Eisenberger, R., Armeli, S., Rexwinkel, B., Lynch, P., \& Rhoades, L. (2001). Reciprocation of perceived organizational support. Journal of Applied Psychology, 86 (1), $42-51$.

Elrod II, P. D., \& Tippett, D. D. (2002). The "death valley" of change" Journal of Organizational Change Management, 15(3), 273-291.

Farrell, D. (1983). Exit, voice, loyalty, and neglect as responses to job dissatisfaction: A multidimensional scaling study. The Academy of Management Journal, 26 (4), 596607.

Foa, U., \& Foa, E. (1974). Societal structures of the mind. Springfield, IL: Charles C Thomas.

Fried, Y., Tiegs, R. B., \& Bellamy, A. R. (1992). Personal and interpersonal predictors of supervisors' avoidance of evaluating subordinates Journal of Applied Psychology, 77(4), 462-468.

Fried, Y. \& Ferris, G. R. (1987). The validity of the job characteristics model: A review and meta - analysis. Personnel Psychology, 40, 287-322. 
Galanou, E. \& Priporas, C. (2009). A model for evaluating the effectiveness of middle managers' training courses: Evidence from a major banking organization in Greece. International Journal of Training and Development, 13 (4), 221-246.

Gaskin, J. (2013). Metric invariance, Gaskination's Statistics. See: http://youtube.com/Gaskination, accessed December 27, 2017

Gentry, W. A., Deal, J. J., Griggs, T. L., Mondore, S. P., \& Cox, B. D. (2011). A comparison of generational differences in endorsement of leadership practices with actual leadership skill level. Consulting Psychology Journal: Practice \& Research, 63(1), $39-49$.

Gibney, R., Zagenczyk, T., \& Masters, M. (2009). The negative aspects of social exchange: An introduction to perceived organizational obstruction. Group \& Organization Management, 34 (6), 665-697.

Gouldner, A. (1960). The norm of reciprocity: A preliminary statement. American Sociological Review, 25 (2), 161-178.

Greenhaus, J., Parasuraman, A., \& Wormley, W. (1990). Effects of race on organizational experiences, job performance evaluations, and career outcomes. Academy of Management Journal, 33 (1), 64-86.

Griffeth, R., \& Hom, P. (1988). A comparison of different conceptualizations of perceived alternatives in turnover research. Journal of Organizational Behavior, 9 (2), 103-111. Gursoy, D., Maier, T. A., \& Chi, C. G. (2008). Generational differences: An examination of work values and generational gaps in the hospitality workforce. International Journal of Hospitality Management, 27 (3), 448-458.

This article is protected by copyright. All rights reserved. 
Hall, D., \& Mirvis, P. (1996). The new protean career: psychological success and the path with a heart. In D. Hall and Associates (Eds.), The career is dead: Long live the career (pp. 15-45). San Francisco: Jossey-Bass.

Hagedoorn, M., Van Yperen, N., Van de Vliert, E., \& Buunk, B. (1999). Employees' reactions to problematic events: A circumplex structure of five categories of responses, and the role of job satisfaction. Journal of Organizational Behavior, 20 (3), 309-321.

Hamori, M., Cao, J., \& Koyunci, B. (2012). Why top young managers are in a nonstop job hunt. Harvard Business Review, 90 (7/8), 28.

Hess, N., \& Jepsen, D. M. (2009). Career stage and generational differences in psychological contracts. Career Development International, 14(2-3), 261-283.

Hess, N., Jepsen, D. M., \& Dries, N. (2012). Career and employer change in the age of the 'boundaryless' career. Journal of Vocational Behavior, 81, 280-288.

Hewlett, S. A., Sherbin, L., \& Sumberg, K. (2009). How Gen Y and Boomers will reshape your agenda. Harvard Business Review (7-8), 71-77.

Holtman, B., Tidd, S., \& Lee, T. (2002). The relationship between work status congruence and work-related attitudes and behaviors. Journal of Applied Psychology, 87 (5), $903-$ 915.

House, J. (1981). Work stress and social support. Reading, MA: Addison-Wesley.

Iverson, R. (1992). Employee intent to stay: An empirical test of a revision of the Price and Mueller model. Unpublished Doctoral Dissertation, University of Iowa.

Jurkiewicz, C. (2000). Generation X and the public employee. Public Personnel Management, 29 (1), 55-74.

This article is protected by copyright. All rights reserved. 
Kaye, B., \& Giulioni, J. (2012). Watch them grow or see them go. San Francisco: BerrettKoehler Publishers.

Kiggundi, M. (1983). Task interdependence and job design: Test of a theory. Organizational Behavior and Human Performance, 31 (2), 145-172.

Kline, R. (1998). Principles and practice of structural equation modeling. New York: Guilford Press.

Kooij, D. T. A. M., \& Boon, C. (2018). Perceptions of HR practices, person-organisation fit, and affective commitment: The moderating role of career stage. Human Resource Management Journal, 28(1), 61-75.

Korsgaard, M., \& Roberson, L. (1995). Procedural justice in performance evaluation: The role of instrumental and non-instrumental voice in performance appraisal discussions. Journal of Management, 21 (4), 657-699.

Kupperschmidt, B. (2000). Multigeneration employees: Strategies for effective management. The Health Care Manager, 19 (1), 65-76.

Lam, S. S. K., Ng, T. W. H., \& Feldman, D. C. (2012). The relationship between external job mobility and salary attainment across career stages. Journal of Vocational Behavior, 80(1), 129-136.

Lyons, S. Schweitzer, L., Ng, E., \& Kuron, L. (2012). Comparing apples to apples: A Qualitative investigation of career mobility patterns across four generations. Career Development International, 17 (4), 333-357.

This article is protected by copyright. All rights reserved. 
Lyons, S. and Kuron, L. (2014). Generational differences in the workplace: A review of the evidence and directions for future research. Journal of Organizational Behavior 35: S139-S157.

Lyons, S. T., Schweitzer, L., \& Ng, E. S. (2015). How have careers changed? An investigation of changing career patterns across four generations. Journal of Managerial Psychology, 30(1), 8-21.

Lyons, S., Duxbury, L., \& Higgins, C. (2005). Are gender differences in basic human values a generational phenomenon? Sex Roles: A Journal of Research (9-10), 763-778.

Mannheim, K. (1952 [1923]). The problem of generations. In P. Kecskemeti (Ed.), Essays on the sociology of knowledge (pp. 276-322). Kecskemeti, Routledge, London

Mathieu, J., \& Zajac, D. (1990). A review and meta-analysis of the antecedents, correlates and consequences of organizational commitment. Psychological Bulletin, 108 (2), 171194.

Morgeson, F. P., \& Hofmann, D. A. (1999). The Structure and Function of Collective Constructs: Implications for Multilevel Research and Theory Development. Academy of Management Review, 24(2), 249-265.

Mullen, T., Kroustalis, C., Meade, A., \& Surface, E. (2006). Assessing change in perceived organizational support due to training. Paper presented at the $21^{\text {st }}$ Annual Conference of the Society for Industrial and Organizational Psychology, Dallas, Txas (April).

Murphy, W. (2012). Reverse mentoring at work: Fostering cross-generational learning and developing millennial leaders. Human Resource Management, 51 (4), 549-574.

This article is protected by copyright. All rights reserved. 
NSA (2017). Pre-Budget Submission. National Seniors Australia. Retrieved July 25, 2017 from: http://www.nationalseniors.com.au

Naus, F., von Iterson, A., \& Roe, R. (2007). Organizational cynicism: Extending the exit, voice, loyalty, and neglect model of employees' responses to adverse conditions in the workplace. Human Relations, 60 (5), 683-718.

Newman, A., Thanacoody, R., \& Hui, W. (2011). The impact of employee perceptions of training on organizational commitment and turnover intentions: A study of multinationals in the Chinese service sector. The International Journal of Human Resource Management, 22 (8), 1765-1787.

Ng, T. W. H., Eby, L. T., Sorensen, K. L., \& Feldman, D. C. (2005). Predictors of objective and subjective career success: a meta-analysis. Personnel Psychology, 58(2), 367-408.

Nishii, L. H., Lepak, D. P., \& Schneider, B. (2008). Employee attributions of the "why" of HR practices: Their effects on employee attitudes and behaviours and customer satisfaction. Personnel Psychology (3), 503-545.

O'Bannon, G. (2001). Managing our future: the generation x factor. Public Personnel Management, 30(1), 95-109.

Porter, L., Steers, R., Mowday, R., \& Boulian, P. (1974). Organizational commitment, job satisfaction, and turnover among psychiatric technicians. Journal of Applied Psychology, 59 (5), 603-609.

Rusbult, C., Farrell, D., Rogers, G., \& Mainous, A. (1988). Impact of exchange variables on exit, voice, loyalty, and neglect: An integrative model of responses to declining job satisfaction. Academy of Management Journal, 31 (3), 599-627.

This article is protected by copyright. All rights reserved. 
Salt, B. (2016). Baby boomers evolve into new generation retirement refuseniks. The Australian, 8 September. Retrieved July 25, 2017 from: http://www.theaustralian.com.au/business/property/baby-boomers-evolve-into-newgeneration-retirement-refuseniks/news-story/58b6b9d4fa19f13ec0551b7f5df7ef6e

Sayer, R. (2007). The right staff from X to Y: Generational change and professional development in future academic libraries. Library Management, 28 (8/9), 474-487.

Shaw, J., Delery, J., Jenkins, G., \& Gupta, N. (1998). An organization-level analysis of voluntary and involuntary turnover. Academy of Management Journal, 41 (5), 511-525.

Seibert, S. \& Kraimer, M. (2001). The five-factor model of personality and career success. The Journal of Vocational Behavior, 58 (1), 1-21.

Shore, L., \& Coyle-Shapiro, J. (2003). Editorial: New Developments in the EmployeeOrganization Relationship. Journal of Organizational Behavior, 24(5), 443-450.

Siemsen, E., Roth, A., \& Oliveira, P. (2010). Common method bias in regression models with linear, quadratic, and interaction effects. Organizational Research Methods, 13 (3), 456-476.

Sirias, D., Karp, H., \& Brotherton, T. (2007). Comparing the levels of individualism / collectivism between baby boomers and generation X: Implications for teamwork. Management Research News, 30 (10), 749-761.

Smola, K., \& Sutton, C. (2002). Generational differences: Revisiting generational work values for the new millennium. Journal of Organizational Behaviour, 23 (4), 363-382. 
Steelman, L., Levy, P., \& Snell, A. (2004). The feedback environment scale: Construct definition, measurement, and validation. Educational and Psychological Measurement, $64(1), 165-184$.

Sullivan, S., \& Arthur, M. (2006). The evolution of the boundaryless career concept: examining physical and psychological mobility. Journal of Vocational Behaviour, 69 (1), 19-29.

Super, D. E. (1957). The psychology of careers. New York: Harper \& Row.

Tansky, J., \& Cohen, D. (2001). The relationship between organizational support, employee development, and organizational commitment: An empirical study. Human Resource Development Quarterly, 12 (3), 285-300.

Twenge, J., Campbell, S., Hoffman, B., \& Lance, C. (2010). Generational differences in work values: Leisure and extrinsic values increasing, social and intrinsic values decreasing. Journal of Management, 36 (5), 1117-1142.

Twenge, J. M., Campbell, W. K., \& Freeman, E. C. (2012). Generational differences in young adults' life goals, concern for others, and civic orientation, 1966-2009. Journal of Personality and Social Psychology, 102(5), 1045-1062.

Van der Heijden, B., Boon, J., Van der Klink, M., \& Meijs, E. (2009). Employability enhancement through formal and informal learning: An empirical study among Dutch non-academic university staff members. International Journal of Training and Development, 13 (1), 19-37. 
Vigoda, E. (2002). Stress-related aftermaths to workplace politics: the relationships among politics, job distress and aggressive behavior in organizations. Journal of Organizational Behavior, 23 (5), 571-591.

Watson, D., Pennebaker, J., \& Folger, R. (1987). Beyond negative affectivity: Measuring stress and satisfaction in the workplace. Journal of Organizational Behavior Management, 8 (2), 141-57.

Weick, K. E. (1995). Sensemaking in organizations. Thousand Oaks, CA: Sage.

Westerman, J. W., \& Yamamura, J. H. (2007). Generational preferences for work environment fit: effects on employee outcomes. Career Development International, $12(2), 150-161$.

Yu, H., \& Miller, P. (2005). Leadership style: The X generation and baby Boomers compared in different cultural contexts. Leadership \& Organization Development Journal, 26 (1), $35-50$.

This article is protected by copyright. All rights reserved. 
Table 1: Descriptive statistics

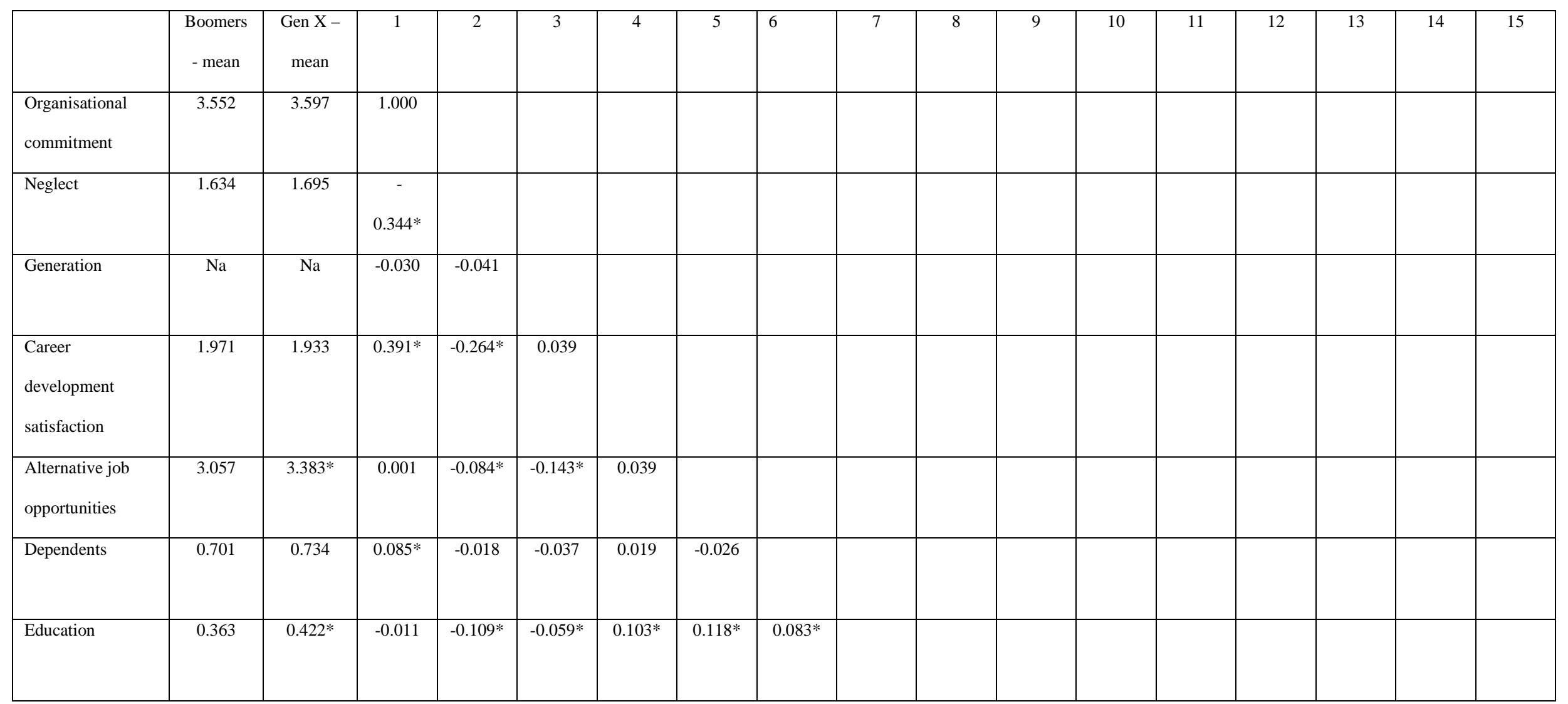




\begin{tabular}{|c|c|c|c|c|c|c|c|c|c|c|c|c|c|c|c|c|c|}
\hline Negative affect & 2.708 & 2.752 & $-0.277^{*}$ & $0.230^{*}$ & -0.021 & $-0.207^{*}$ & $-0.069^{*}$ & $-0.079^{*}$ & $0.052^{*}$ & & & & & & & & \\
\hline Co-worker support & 3.626 & $3.736^{*}$ & $0.263^{*}$ & $-0.119^{*}$ & $-0.060^{*}$ & $0.269^{*}$ & $0.063^{*}$ & $\begin{array}{c}-0.014 \\
\end{array}$ & -0.020 & $-0.187^{*}$ & & & & & & & \\
\hline $\begin{array}{l}\text { Performance } \\
\text { feedback }\end{array}$ & 3.275 & $3.436^{*}$ & $0.265^{*}$ & $-0.192^{*}$ & $-0.081^{*}$ & $0.216^{*}$ & -0.006 & 0.012 & $-0.065 *$ & $-0.178^{*}$ & $0.284^{*}$ & & & & & & \\
\hline Union & 0.745 & $0.654^{*}$ & 0.013 & $0.057^{*}$ & $0.098^{*}$ & \begin{tabular}{c|c|}
-0.006 \\
\end{tabular} & $-0.119^{*}$ & 0.018 & -0.034 & $0.082^{*}$ & 0.042 & 0.004 & $0.053^{*}$ & & & & \\
\hline $\begin{array}{l}\text { Resource } \\
\text { adequacy }\end{array}$ & 3.224 & $3.312^{*}$ & $0.405^{*}$ & $-0.179^{*}$ & $-0.056^{*}$ & $0.338^{*}$ & -0.002 & -0.007 & -0.042 & $-0.309^{*}$ & $0.308^{*}$ & $0.254 *$ & $-0.063^{*}$ & -0.023 & & & \\
\hline $\begin{array}{l}\text { maintenance } \\
\text { career stage }\end{array}$ & 0.733 & $0.452^{*}$ & -0.044 & $0.055^{*}$ & $0.281^{*}$ & $0.055^{*}$ & $-0.255^{*}$ & 0.034 & $-0.126^{*}$ & 0.043 & 0.015 & $-0.094^{*}$ & $0.063^{*}$ & $0.287^{*}$ & $-0.052^{*}$ & $-0.381^{*}$ & $-0.812^{*}$ \\
\hline
\end{tabular}

This article is protected by copyright. All rights reserved. 
NB: * $\mathrm{p}<.05 ; \mathrm{n}=1530$; asterisks in "Mean Gen X" column indicate that there is a statistically significant difference between the mean of Boomers and Gen X on the variable 
Table 2: Organisational commitment, neglect of work and career development satisfaction: the moderating role of Generation

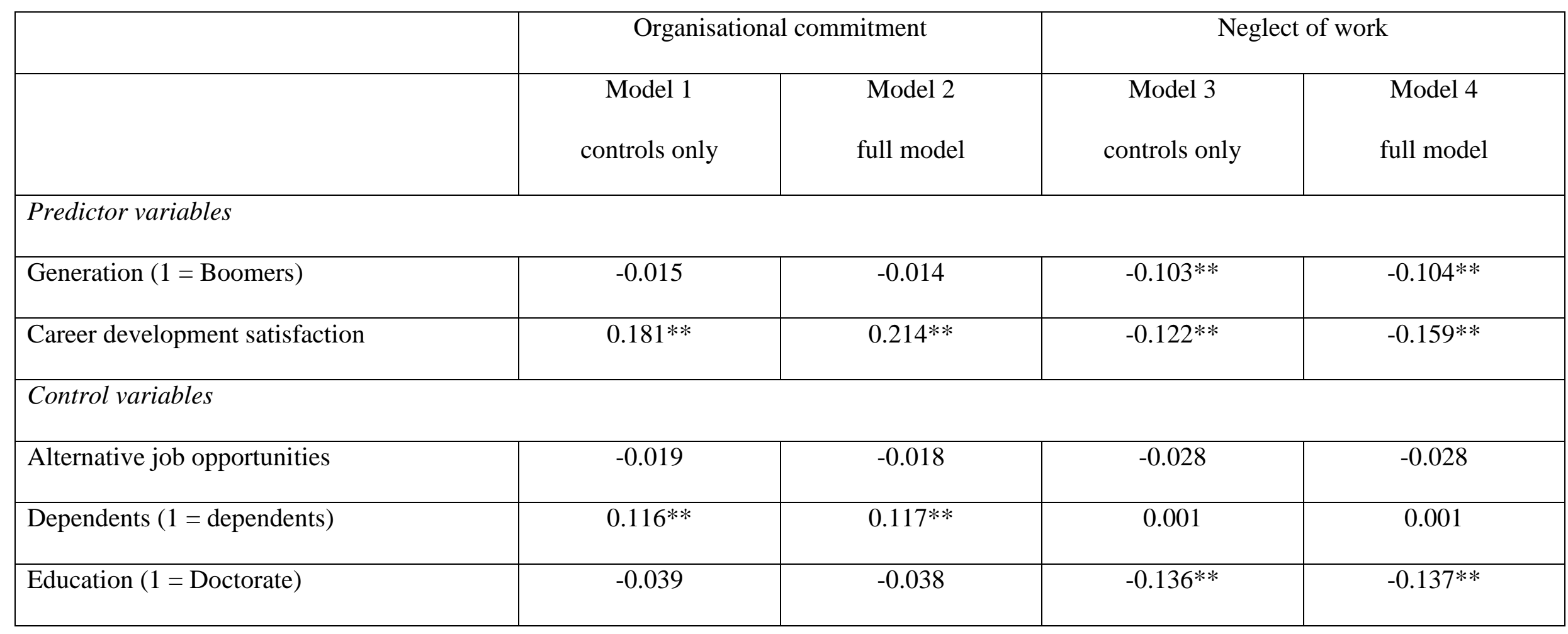

This article is protected by copyright. All rights reserved. 


\begin{tabular}{|c|c|c|c|c|}
\hline Negative affect & $-0.085 * *$ & $-0.086 * *$ & $0.116 * *$ & $0.117 * *$ \\
\hline Task interdependence & $0.040^{*}$ & $0.041 *$ & $-0.076 * *$ & $-0.077 * *$ \\
\hline Resource adequacy & $0.221 * *$ & $0.221 * *$ & $-0.055^{*}$ & $-0.055^{*}$ \\
\hline establishment career stage & 0.058 & 0.061 & -0.089 & -0.092 \\
\hline advancement career stage & $0.092 *$ & $0.093 *$ & -0.047 & -0.048 \\
\hline Constant & $2.437 * *$ & $2.419 * *$ & $2.243 * *$ & $2.262 * *$ \\
\hline
\end{tabular}

This article is protected by copyright. All rights reserved. 


\begin{tabular}{|l|c|c|c|}
\hline Adj R-squared & .276 & .278 & .137 \\
\hline Change in Adj R-squared & & .003 & .140 \\
\hline $\mathrm{F}\left(\mathrm{df}_{1}, \mathrm{df}_{2}\right)$ & & $5.518^{*}(1,1516)$ & $5.336^{*}(1,1516)$ \\
\hline
\end{tabular}

unstandardized coefficients; $* *$ p $<.01 ; * \mathrm{p}<.05$ 


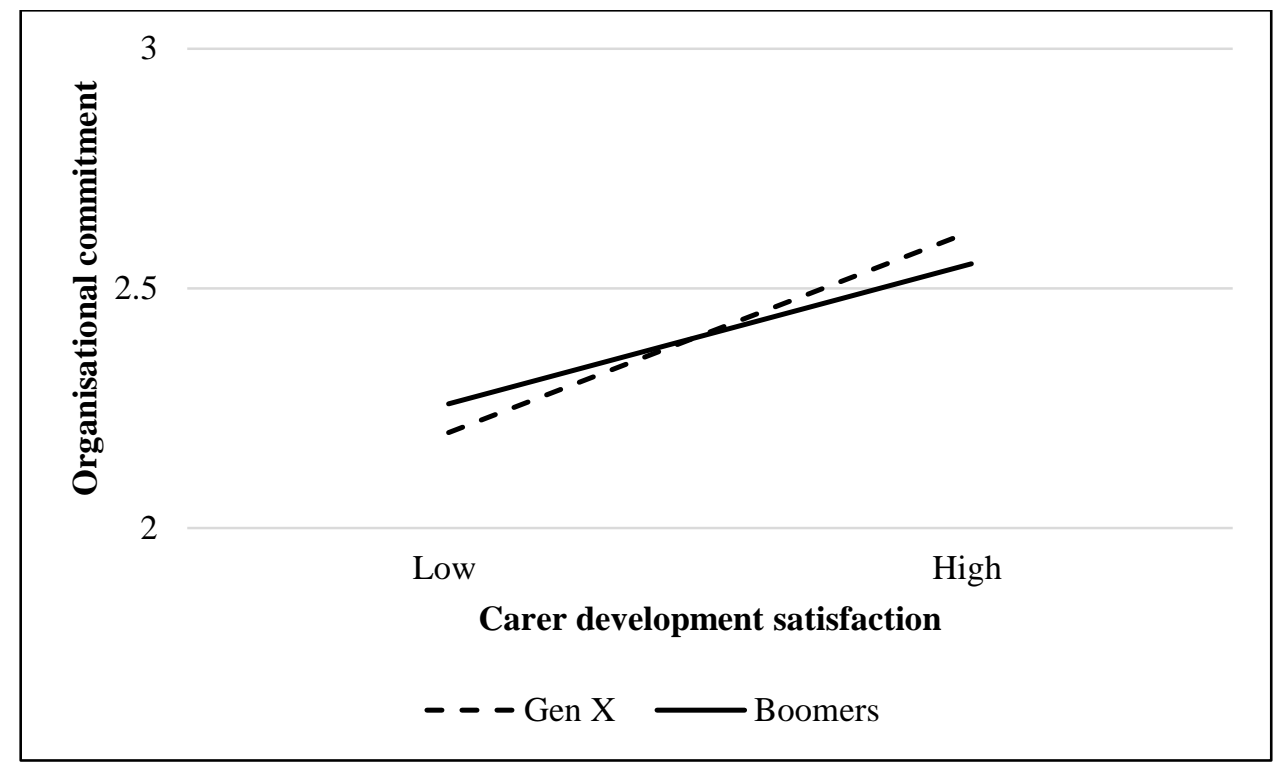

Figure 1: Interaction of Career Development Satisfaction X Generation Predicting Organisational Commitment 


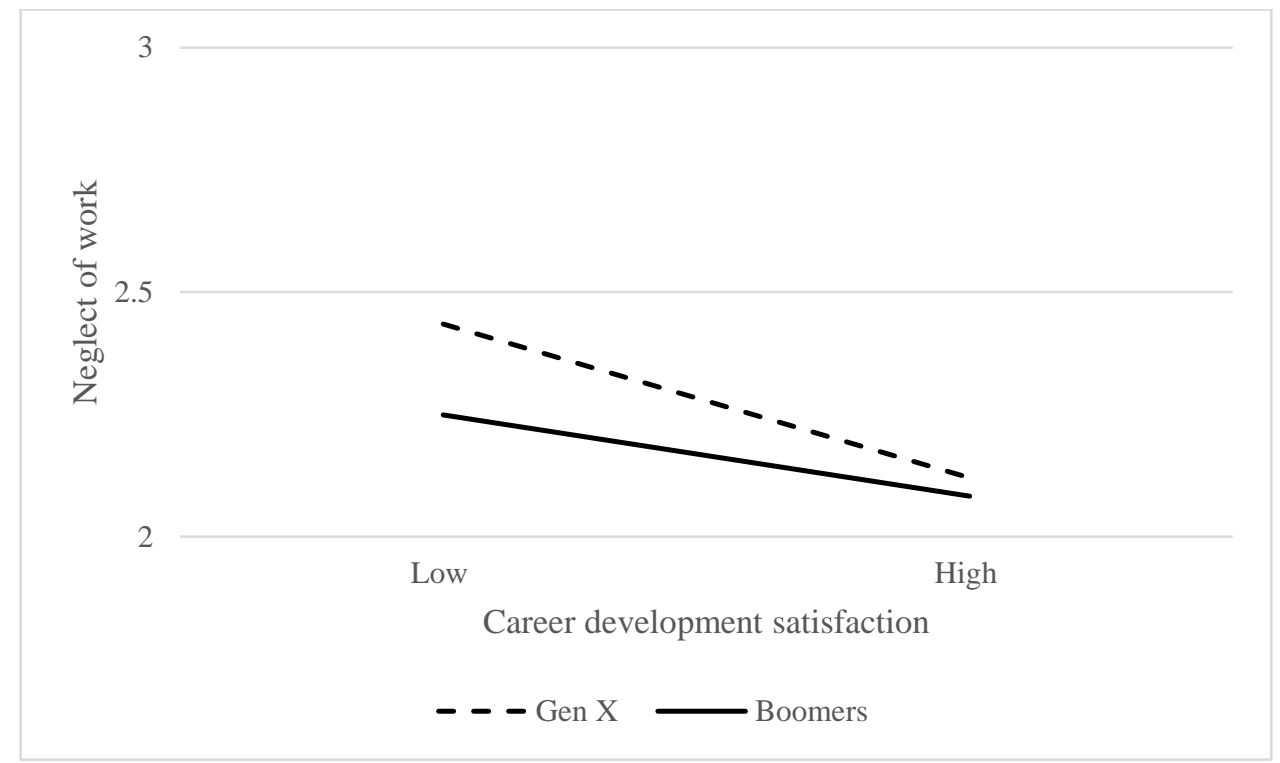

Figure 2: Interaction of Career Development Satisfaction X Generation Predicting Neglect of Work 


\section{University Library}

\section{- M M N E R VA A gateway to Melbourne's research publications}

Minerva Access is the Institutional Repository of The University of Melbourne

Author/s:

Benson, J;Brown, M;Glennie, M;O'Donnell, M;O'Keefe, P

Title:

The generational "exchange" rate: How generations convert career development satisfaction into organisational commitment or neglect of work

Date:

2018-11-01

Citation:

Benson, J., Brown, M., Glennie, M., O'Donnell, M. \& O'Keefe, P. (2018). The generational "exchange" rate: How generations convert career development satisfaction into organisational commitment or neglect of work. HUMAN RESOURCE MANAGEMENT JOURNAL, 28 (4), pp.524-539. https://doi.org/10.1111/1748-8583.12198.

Persistent Link:

http://hdl.handle.net/11343/283979 